\title{
Significant recent warming over the northern Tibetan Plateau from ice core $\delta^{18} \mathrm{O}$ records
}

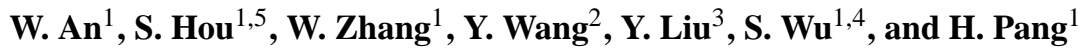 \\ ${ }^{1}$ Key Laboratory of Coast and Island development of Ministry of Education, School of Geographic and Oceanographic \\ Sciences, Nanjing University, Nanjing 210093, China \\ ${ }^{2}$ College of Population, Resources and Environment, Shandong Normal University, Jinan 250014, China \\ ${ }^{3}$ State Key Laboratory of Cryospheric Science, Cold and Arid Regions Environmental and Engineering Research Institute, \\ Chinese Academy of Sciences, Lanzhou 730000, China \\ ${ }^{4}$ Geology Department, University of Dayton, Ohio 45469-2364, USA \\ ${ }^{5}$ CAS Center for Excellence in Tibetan Plateau Earth Sciences, Beijing 100101, China
}

Correspondence to: S. Hou (shugui@nju.edu.cn)

Received: 13 May 2015 - Published in Clim. Past Discuss.: 2 July 2015

Revised: 19 November 2015 - Accepted: 19 January 2016 - Published: 5 February 2016

\begin{abstract}
Stable oxygen isotopic records in ice cores provide valuable information about past temperature, especially for regions with scarce instrumental measurements. This paper presents the $\delta^{18} \mathrm{O}$ result of an ice core drilled to bedrock from Mt. Zangser Kangri (ZK), a remote area on the northern Tibetan Plateau (TP). We reconstructed the temperature series for 1951-2008 from the $\delta^{18} \mathrm{O}$ records. In addition, we combined the $\mathrm{ZK} \delta^{18} \mathrm{O}$ records with those from three other ice cores in the northern TP (Muztagata, Puruogangri, and Geladaindong) to reconstruct a regional temperature history for the period 1951-2002 (RTNTP). The RTNTP showed significant warming at $0.51 \pm 0.07^{\circ} \mathrm{C}(10 \mathrm{yr})^{-1}$ since 1970 , a higher rate than the trend of instrumental records of the northern TP $\left(0.43 \pm 0.08^{\circ} \mathrm{C}(10 \mathrm{yr})^{-1}\right)$ and the global temperature trend $\left(0.27 \pm 0.03^{\circ} \mathrm{C}(10 \mathrm{yr})^{-1}\right)$ at the same time. In addition, the $\mathrm{ZK}$ temperature record, with extra length until 2008, seems to suggest that the rapid elevation-dependent warming continued for this region during the last decade, when the mean global temperature showed very little change. This could provide insights into the behavior of the recent warming hiatus at higher elevations, where instrumental climate records are lacking.
\end{abstract}

\section{Introduction}

With an average elevation over $4000 \mathrm{~m}$ a.s.l., the Tibetan Plateau (TP) is the highest and most extensive highland in the world. In recent decades, it has experienced rapid warming and drastic environmental changes such as fast glacier retreat and land deterioration (Yao et al., 2012). In recent years, the global average surface temperature has experienced relatively little change (Easterlin and Wehner, 2009), whereas accelerated warming has continued on the TP for the same period of time (Yan and Liu, 2014; Duan and Xiao, 2015). However, the rapid warming trend over the plateau was established with data from meteorological stations located at relatively low elevations, and the warming trend for higherelevation regions remains uncertain.

In addition, spatial biases also exist in the TP temperature records. Most instrumental records as well as various paleoclimate proxies are located in the eastern and southern plateau (Thompson et al., 2000; B. Yang et al., 2014; Herzschuh et al., 2010; Pu et al., 2011). There is generally a lack of climate data in the northern TP, and particularly in the northwest TP, where meteorological stations were sparse and long-term high-resolution climate records were difficult to obtain because of the formidable terrain and harsh environment. However, the northern TP (Fig. 1) is a climatologically important region involving complicated interactions between the midlatitude westerlies and the subtropical Asia monsoon circulation. It may serve as a bridge linking the 


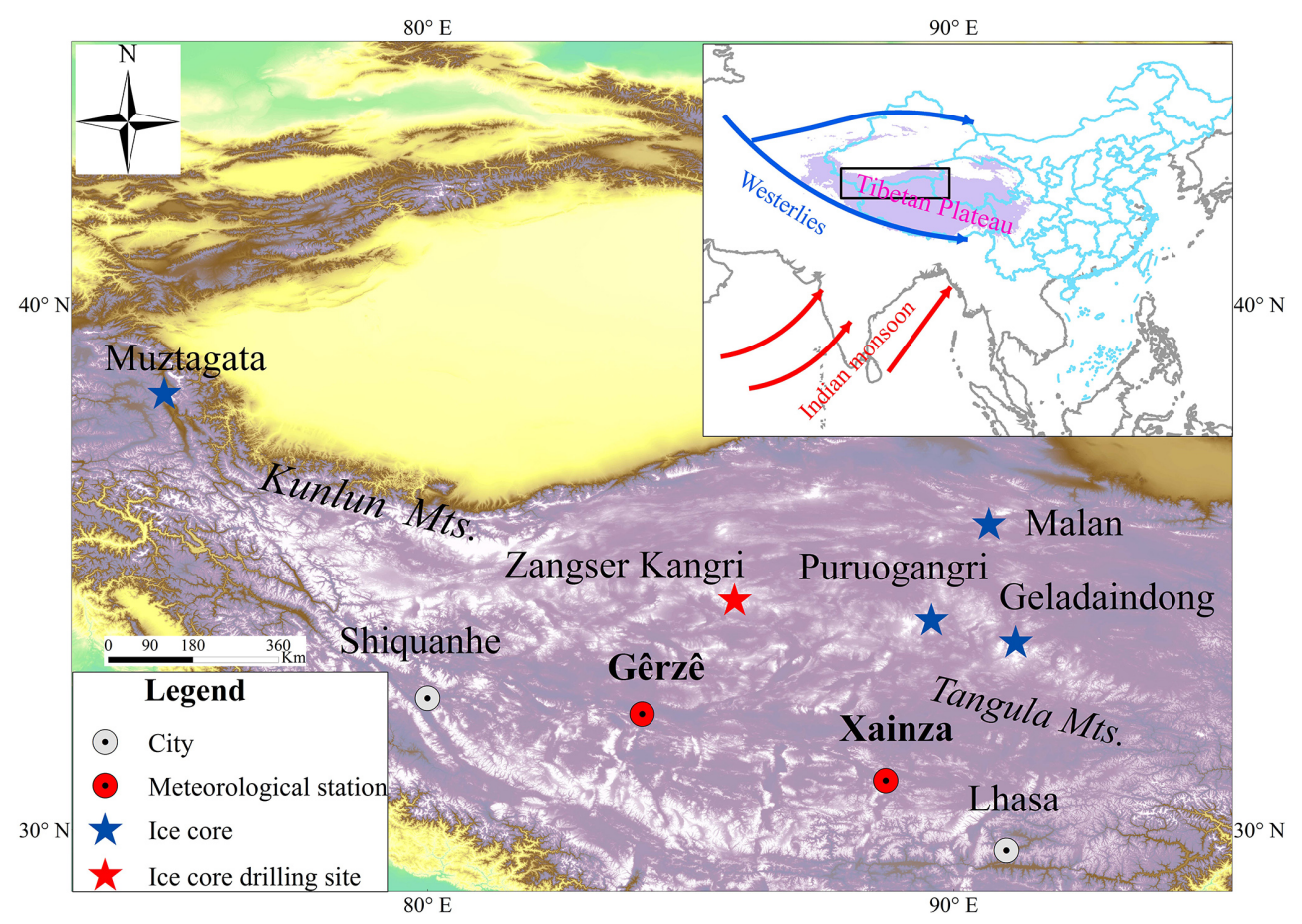

Figure 1. Location of the ice core drilling site of ZK, two nearby meteorological station sites, and the location of other ice cores described in the text: Muztagata (Tian et al., 2006), Puruogangri (Yao et al., 2006), Geladaindong (Kang et al., 2007), and Malan (Wang et al., 2003) over the northern TP. The inset shows the relative location of the northern TP to the entire TP. The black rectangle indicates the study area. Red and blue arrows represent the circulation patterns for the study region. Red arrows indicate the direction of the Indian monsoon (near surface) in summer, and blue arrows indicate the dominant westerlies (mid- to upper troposphere) in winter.

high- and low-latitude climatic processes (He et al., 2013). It is therefore essential to evaluate the extent and magnitude of regional climate changes over this region without coverage bias.

The ice core $\delta^{18} \mathrm{O}$ is an important paleoclimate proxy on the TP (Thompson et al., 2000; Qin et al., 2002) and has been generally considered to be a reliable indicator for past temperatures (Yao et al., 2006; Joswiak et al., 2010). However, great discrepancies still exist among different temperature reconstructions and instrumental records owing to the distinct geographic locations and atmospheric circulation conditions (Liu and Chen, 2000; N. Wang et al., 2003; Y. Q. Wang et al., 2003; Yao et al., 2006). Therefore, it is important to establish more high-resolution temperature records on the TP, particularly over such extensive high-elevation regions as the northern TP, in order to evaluate the warming trends at high elevations in light of the recent warming hiatus. In this study, we measured the $\delta^{18} \mathrm{O}$ values in an ice core drilled from the Zangser Kangri (ZK) glacier on the northern TP, from which temperature changes in the past decades could be established. The ZK ice core $\delta^{18} \mathrm{O}$ records made it possible to study the past climate variations over a relatively inaccessible part of the TP, where instrumental records are very limited. In addition, we also established the regional climate change history by combining ZK with the $\delta^{18} \mathrm{O}$ records from other ice cores in the northern TP.

\section{Methodology and data}

\subsection{Research area and ice core dating}

The ZK glacier is located in the northwest part of the TP, covering an area of $337.98 \mathrm{~km}^{2}$ with a volume of $41.70 \mathrm{~km}^{3}$ (2005 data, Shi, 2008). The snow line is about 5700 5940 ma.s.l. In April of 2009, two ice cores to bedrock (127.7 and $126.7 \mathrm{~m}$ in length for core 1 and core 2, respectively) were recovered from the glacier $\left(34^{\circ} 18^{\prime} 05.8^{\prime \prime} \mathrm{N}\right.$, $85^{\circ} 51^{\prime} 14.2^{\prime \prime}$ E, $6226 \mathrm{~m}$ a.s.1., Fig. 1). The glacier temperature ranged from -15.2 to $-9.2^{\circ} \mathrm{C}$, with a mean temperature of $-11.7^{\circ} \mathrm{C},-12.4^{\circ} \mathrm{C}$ at $10 \mathrm{~m}$ depth and a basal temperature of $-9.2^{\circ} \mathrm{C}$.

These two ice cores were kept frozen and transported to the State Key Laboratory of Cryospheric Sciences, Cold and Arid Regions Environmental and Engineering Research Institute, Chinese Academy of Sciences, for processing. This study was based upon the analysis of core 1 . A total of 2884 samples were taken from core 1 at a resolution of 4$6 \mathrm{~cm}$. The outer $\sim 2 \mathrm{~cm}$ of each sample was removed for stable oxygen isotope analysis. The inner portion of the ice core was collected in pre-cleaned polyethylene sample con- 


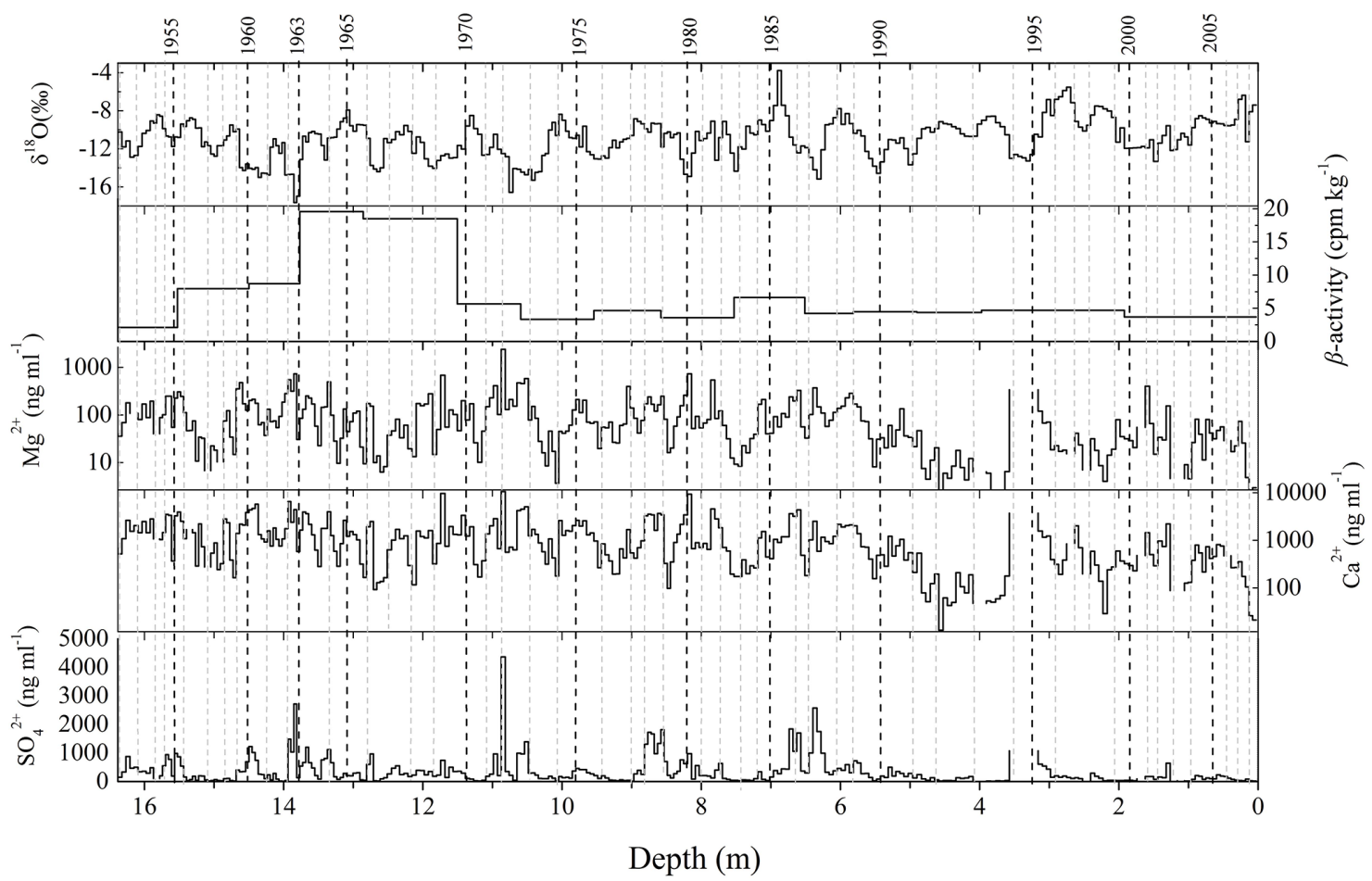

Figure 2. Variations of $\delta^{18} \mathrm{O}$ in the $\mathrm{ZK}$ ice core and other data used for dating, including beta activity and major ion concentrations. We calculated the logarithm to the base 10 for the concentrations of the $\mathrm{Ca}^{2+}$ and $\mathrm{Mg}^{2+}$ to facilitate dating.

tainers for chemical and dust particle analyses. Stable oxygen isotope ratio $\left(\delta^{18} \mathrm{O}\right)$ was determined using a Picarro Wavelength-Scanned Cavity Ring-Down Spectrometer (WSCRDS, model L2120i). Major cations and anions were analyzed using a Dionex-600 and ICS-2500 ion chromatograph, respectively.

In the northern TP, the annual cycle of $\delta^{18} \mathrm{O}$ along the ice core profile is primarily related to temperature variations (Araguás-Araguás et al., 1998; Yao et al., 2013). The $\delta^{18} \mathrm{O}$ compositions in modern precipitation samples collected in the northern TP show marked seasonal patterns, with high values in summer and low values in winter (Yu et al., 2009). In addition, the major ions (e.g., $\mathrm{Mg}^{2+}$ and $\mathrm{SO}_{4}^{2-}$ ) also show clear seasonal cycles with high concentrations in winter/spring and low concentrations in summer (Zheng et al., 2010). They have been used in past studies as complementary tools in ice core dating in the northern TP (Kang et al., 2007). Therefore, the $Z K$ ice core was dated by using the seasonality of $\delta^{18} \mathrm{O}$ in conjunction with the seasonal variations of major ions, including $\mathrm{Mg}^{2+}, \mathrm{Ca}^{2+}$, and $\mathrm{SO}_{4}^{2-}$, with a reference layer of $\beta$ activity peak in 1963 (Fig. 2). Core 1 was dated back to 1951 at $16.38 \mathrm{~m}$ depth with uncertainty estimated within 1 year (Fig. 2; Zhang et al., 2016). Based on the dating result and density of the ice core profile, the mean annual net accumulation rate was estimated to be low for ZK glaciers $\left(190 \mathrm{~kg} \mathrm{H}_{2} \mathrm{O} \mathrm{m}^{-1} \mathrm{yr}^{-1}\right)$. This study focused on the $\delta^{18} \mathrm{O}$ records in the top $16.38 \mathrm{~m}$ of the ice core, corresponding to the time period 1951-2008.

\subsection{Climate data}

The ZK glacier is located at a transition zone with shifting influences between the westerlies and the Indian summer monsoon (Yao et al., 2013). Based on the climate records from the two nearby meteorological stations, at Gêrzê $\left(32^{\circ} 09^{\prime}\right.$, $84^{\circ} 25^{\prime}, 4414.9 \mathrm{~m}$ a.s.l., $\left.1973-2008\right)$ and Xainza $\left(30^{\circ} 57^{\prime}\right.$, $88^{\circ} 38^{\prime}$, 4800 m a.s.1., 1961-2008) (Fig. 1), the local mean monthly temperature ranges from $-10.8^{\circ} \mathrm{C}$ in January to $10.7^{\circ} \mathrm{C}$ in July, with an annual average of $0^{\circ} \mathrm{C}$. Precipitation averages $257 \mathrm{~mm}$ per year, of which $75 \%$ falls between June and September (Supplement Fig. S1a).

In order to establish the representativeness of the $\mathrm{ZK}$ ice core $\delta^{18} \mathrm{O}$ for the regional climate, we performed correlation analysis, using Pearson's correlation coefficient $(r)$, between the ice core $\delta^{18} \mathrm{O}$ time series and temperature records from the nearby meteorological stations (Gêrzê and Xainza), and the instrumental temperature series from a network of meteorological stations in the northern TP (hereafter, ITNTP). The ITNTP time series was derived from 14 climate stations used in Guo and Wang (2011), and was extended to 2014 based on the data provided by the Data and Information Center, China Meteorological Administration. It should be noted that most of the stations used in ITNTP time series were located in the 
eastern part of the northern TP, with altitudes ranging from 2767 to $3367 \mathrm{~m}$ (Guo and Wang, 2011), whereas this study focused on the higher $(>5700 \mathrm{~m})$ and more extensive western part of the northern TP (Fig. 1). In addition, spatial correlations were carried out between $\mathrm{ZK} \delta^{18} \mathrm{O}$ and the CRU 4 gridded temperature reanalysis data (Mitchell and Jones, 2005) on the KNMI Climate Explorer (http://climexp.knmi.nl).

In this study, in addition to the ZK series, we also attempted to reconstruct a regional temperature series by combining ZK with other ice core $\delta^{18} \mathrm{O}$ records in the northern TP, including Muztagata (Tian et al., 2006), Puruogangri (Yao et al., 2006), Geladaindong (Kang et al., 2007), and Malan (N. Wang et al., 2003) (Fig. 4 and Table 2). We first examined the consistency of these ice core records and excluded Malan from the reconstruction because of its drastically different temporal patterns from the rest of the records. To combine the remaining four ice core records, we derived the $\delta^{18} \mathrm{O}$ anomalies for each ice core series to eliminate the difference in the absolute values and calculated their average (Fig. S2), which was then used to reconstruct the regional temperature time series.

\section{Results and discussion}

\subsection{The ZK ice core $\delta^{18} \mathrm{O}$ variation and its relationship with regional meteorological data}

The raw $\delta^{18} \mathrm{O}$ values throughout the $\mathrm{ZK}$ ice core profile from 1951 to 2008 are presented in Fig. 2. For this section, the $\delta^{18} \mathrm{O}$ values ranged from $-17.65 \%$ at $13.8 \mathrm{~m}$ to $-3.79 \%$ o at $6.85 \mathrm{~m}$, with an average value of $-10.97 \%$ (Fig. 2). The $\delta^{18} \mathrm{O}$ values were relatively low in the 1960 s, followed by an increasing trend from the 1970s to the end of the record.

Stable oxygen isotope in precipitation could be affected by a variety of environmental factors. In addition to temperature, the $\delta^{18} \mathrm{O}$ values in ice cores could also be affected by precipitation seasonality and amount (Dansgaard, 1964). To exclude possible influence of precipitation, we first examined whether the seasonal distribution of precipitation experienced any significant changes during the study period by using the precipitation records from the two nearby stations. Results showed weak positive trends for the proportion of precipitation in winter and spring, and no statistically significant trends for the proportions of precipitation in summer and fall (Fig. S1b and c). This suggests that changes in seasonal distribution of precipitation did not exert a major influence on the $\delta^{18} \mathrm{O}$ values in $\mathrm{ZK}$ ice cores during the period 1961-2008. Furthermore, we found no significant correlation between the $\mathrm{ZK} \delta^{18} \mathrm{O}$ record and precipitation amount recorded at the stations (Table S1 in the Supplement). Partial correlation analysis showed this to be true even when annual temperature was controlled $\left(r_{\text {partial }}=0.01, p>0.1\right)$. This suggests that precipitation amount had little influence on the $\mathrm{ZK} \delta^{18} \mathrm{O}$ values.

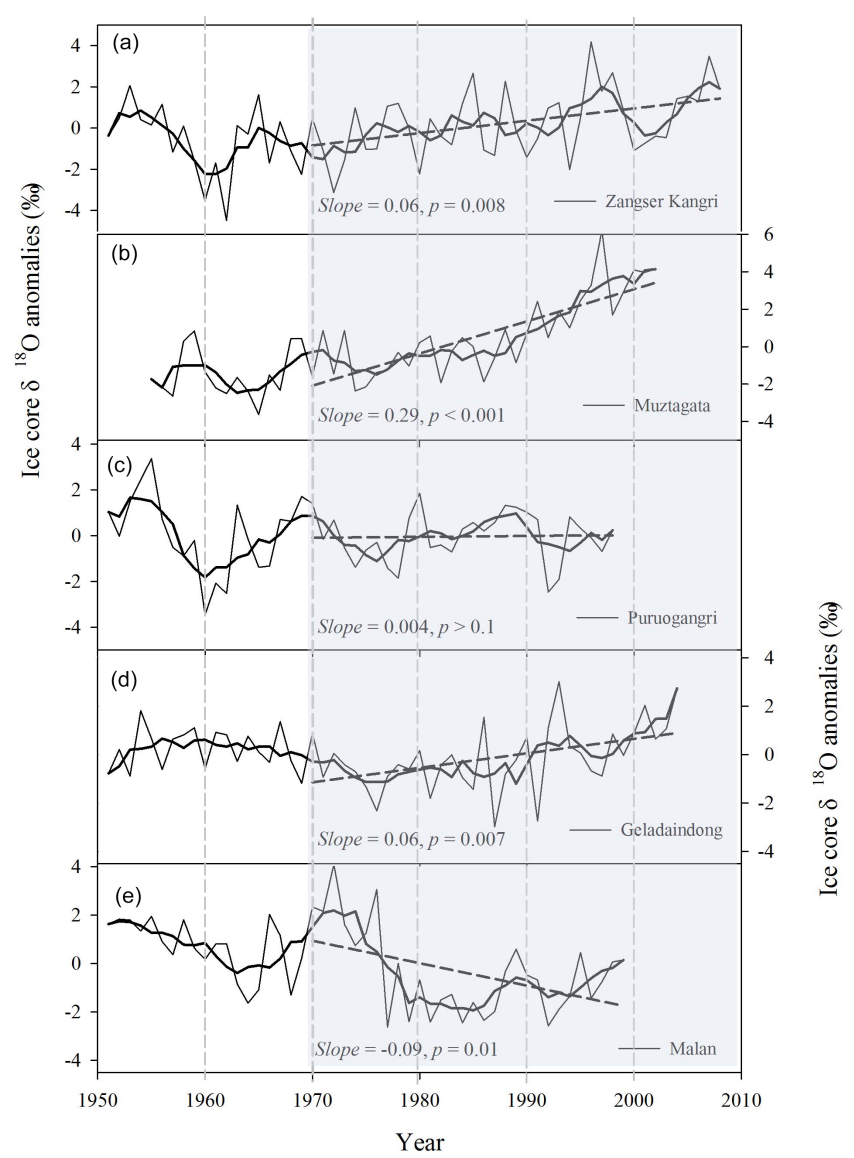

Figure 3. Comparisons of the anomalies of $\delta^{18} \mathrm{O}$ records in the $\mathrm{ZK}$ ice core (a) with $\delta^{18} \mathrm{O}$ records from Muztagata (b), Puruogangri (c), Geladaindong (d), and Malan ice cores (e). Thin lines represent annual values, thick lines the 5-year running averages, and the dashed lines the linear trends since 1970.

On the other hand, the $\mathrm{ZK} \delta^{18} \mathrm{O}$ time series showed positive correlation with annual temperature measured at each of the nearby stations ( $r=0.31, p=0.07$ for the Gêrzê station; $r=0.43, p=0.002$ for the Xainza station), the mean annual temperature of the two stations $(r=0.34, p=0.01)$, and ITNTP $(r=0.35, p=0.02)$ (Table 1$)$. Stronger correlation existed between the ZK $\delta^{18} \mathrm{O}$ and spring (March-May) temperature of the stations (Table 1). Linear regressions led to a mean $\delta^{18} \mathrm{O}$-temperature slope of $0.85 \% 0^{\circ} \mathrm{C}^{-1}$ with values ranging from 0.67 to $0.98 \% 0^{\circ} \mathrm{C}^{-1}$ (Table 1). This is consistent with the published $\delta^{18} \mathrm{O}$-temperature relationships derived from ice cores over the northern TP (X. X. Yang et al., 2014).

Significant spatial correlation existed between the ZK $\delta^{18} \mathrm{O}$ series and the CRU gridded temperature data in the region surrounding the drilling site. The $\mathrm{ZK} \delta^{18} \mathrm{O}$ series showed positive correlations with annual mean and minimum temperatures for most of the northern TP (Fig. 3). The most significant and spatially extensive correlations were found between the $\mathrm{ZK} \delta^{18} \mathrm{O}$ and spring temperatures (Fig. 3c 
Table 1. Correlation coefficients and linear slopes between the $\delta^{18} \mathrm{O}$ values in the ZK ice core and instrumental spring (March-May) and annual temperature from closest stations, Gêrzê (1973-2008) and Xainza stations (1961-2008); the averaged records of the two stations (1961-2008); and the ITNTP series (1961-2008).

\begin{tabular}{lllllllll}
\hline & & \multicolumn{2}{c}{ Gêrzê } & \multicolumn{2}{c}{ Xainza } & \multicolumn{2}{c}{ Station averaging } & \multicolumn{2}{c}{ ITNTP } \\
\cline { 3 - 7 } & & March-May & Annual & March-May & Annual & March-May & Annual & Annual \\
\hline \multirow{2}{*}{ Correlation coefficients } & Annual & $0.52^{* * *}$ & $0.34^{* *}$ & $0.45^{* * *}$ & $0.34^{* *}$ & $0.48^{* * *}$ & $0.34^{* *}$ & $0.35^{*}$ \\
\multirow{3}{*}{ Slope } & 5-year running average & $0.63^{* * *}$ & $0.53^{* * *}$ & $0.73^{* * *}$ & $0.60^{* * *}$ & $0.73^{* * *}$ & $0.60^{* * *}$ & $0.61^{* * *}$ \\
& Annual & $0.93^{* *}$ & $0.67^{* *}$ & $0.93^{* *}$ & $0.98^{* *}$ & $1.00^{* * *}$ & $0.88^{* *}$ & $0.87^{*}$ \\
& 5-year running average & $0.87^{* * *}$ & $0.76^{* * *}$ & $1.54^{* * *}$ & $1.32^{* * *}$ & $1.37^{* * *}$ & $1.18^{* * *}$ & $0.40^{* * *}$ \\
\hline
\end{tabular}

${ }^{*} p<0.05 ;{ }^{* *} p<0.01 ;{ }^{* * *} p<0.001$.

Table 2. Basic information of ice cores from the northern TP.

\begin{tabular}{llllll}
\hline Ice core & Muztagata & ZK & Puruogangri & Geladaindong & Malan \\
\hline Latitude (N) & $38^{\circ} 17^{\prime} \mathrm{N}$ & $34^{\circ} 18^{\prime} 05.8^{\prime \prime} \mathrm{N}$ & $33^{\circ} 54^{\prime} \mathrm{N}$ & $33^{\circ} 34^{\prime} 37.8^{\prime \prime} \mathrm{N}$ & $35^{\circ} 50^{\prime} \mathrm{N}$ \\
Longitude (E) & $75^{\circ} 06^{\prime \prime} \mathrm{E}$ & $85^{\circ} 51^{\prime} 14.2^{\prime \prime} \mathrm{E}$ & $86^{\circ} 06^{\prime} \mathrm{E}$ & $91^{\circ} 10^{\prime} 35.3^{\prime \prime} \mathrm{E}$ & $90^{\circ} 40^{\prime} \mathrm{E}$ \\
Altitude (m) & 7010 & 6226 & 6200 & 5720 & 5680 \\
\hline
\end{tabular}

and d), which were consistent with previous results between the $\mathrm{ZK} \delta^{18} \mathrm{O}$ series and station temperature records (Table 1). The stronger spring temperature signal recorded in the $\mathrm{ZK} \delta^{18} \mathrm{O}$ record may be attributed to the different seasonal moisture sources in this region. At Shiquanhe and Gêrzê, Yu et al. (2009) found that during the non-monsoon period (October-June), when local moisture recycling and the westerlies dominate the moisture sources, air temperature correlates more strongly with $\delta^{18} \mathrm{O}$ in precipitation. On the other hand, precipitation $\delta^{18} \mathrm{O}$ in the monsoon season could be affected by a variety of factors other than temperature, including the convection intensity, distance from moisture sources, and amount effect (He et al., 2015; Tang et al., 2015). This could obscure the relationship between $\delta^{18} \mathrm{O}$ and air temperatures (Joswiak et al., 2013). In addition, previous studies in the central Himalayas found that high-elevation areas (> $3000 \mathrm{~m}$ a.s.l.) can receive up to $40 \%$ of their annual precipitation during the cold season because of terrain-locked low-pressure systems and orographically forced precipitation (Lang and Barros, 2004), a much higher percentage than that of surrounding low-altitude areas of the same region (Pang et al., 2014). Therefore, the ZK ice core (located at $6226 \mathrm{~m}$ a.s.l.) could have had more cold-season (nonmonsoonal) precipitation than that indicated by nearby meteorological stations, located at much lower elevations. Both factors could result in a stronger signal of spring temperature in the ZK ice core $\delta^{18} \mathrm{O}$ record.

\subsection{Regional temperature reconstruction}

Detailed comparisons were made between the $\mathrm{ZK} \delta^{18} \mathrm{O}$ and the $\delta^{18} \mathrm{O}$ time series of four nearby ice cores, including Muztagata, Puruogangri, Geladaindong, and Malan (Fig. 4 and Table 2). The cooling around the 1960 s was present in all ice cores, and this was consistent with the observed cold period during this time over the entire TP (Liu and Chen, 2000). Moreover, the significant increasing trend from the 1970s to present was observed in all except the Malan ice core $\delta^{18} \mathrm{O}$ series. We calculated the Pearson correlation coefficients among these ice core $\delta^{18} \mathrm{O}$ series (Table 3). The results showed weak correlations between the annual values of these series. This lack of correlation could result from the differences in location, elevation, and hence local climates. It could also arise from uncertainties in ice core dating. In order to reduce the impact of dating uncertainties, we used the 5 -year running averages instead of annual values, and these series showed much stronger correlations, suggesting possible common regional climate patterns preserved in these ice core series. This coherence is important when we use the average of multiple sites to develop a regional composite.

In contrast to the rest of the ice cores, the Malan $\delta^{18} \mathrm{O}$ record showed a cooling trend since the 1970s (Fig. 4e). Such a continuous low level of $\delta^{18} \mathrm{O}$ could be caused by the change of local climate conditions (Y. Q. Wang et al., 2003), but it could also result from post-depositional processes on the chemical profiles, such as summer melting, evaporation, and condensation, all of which could modify the relationship between ice core $\delta^{18} \mathrm{O}$ and temperature (Hou et al., 2006). Furthermore, the correlation analysis showed that the Malan time series was negatively correlated with the other four time series, and the negative relationships were more significant after 5-year running averaging (Table 3). Therefore, we excluded the Malan record from further analysis.

Moreover, the correlations between Geladaindong and the three other ice cores - i.e., ZK, Muztagata, and Puruogangri - were relatively low even after 5-year running averaging (Table 3). The lack of correlation could be attributed to its lo- 

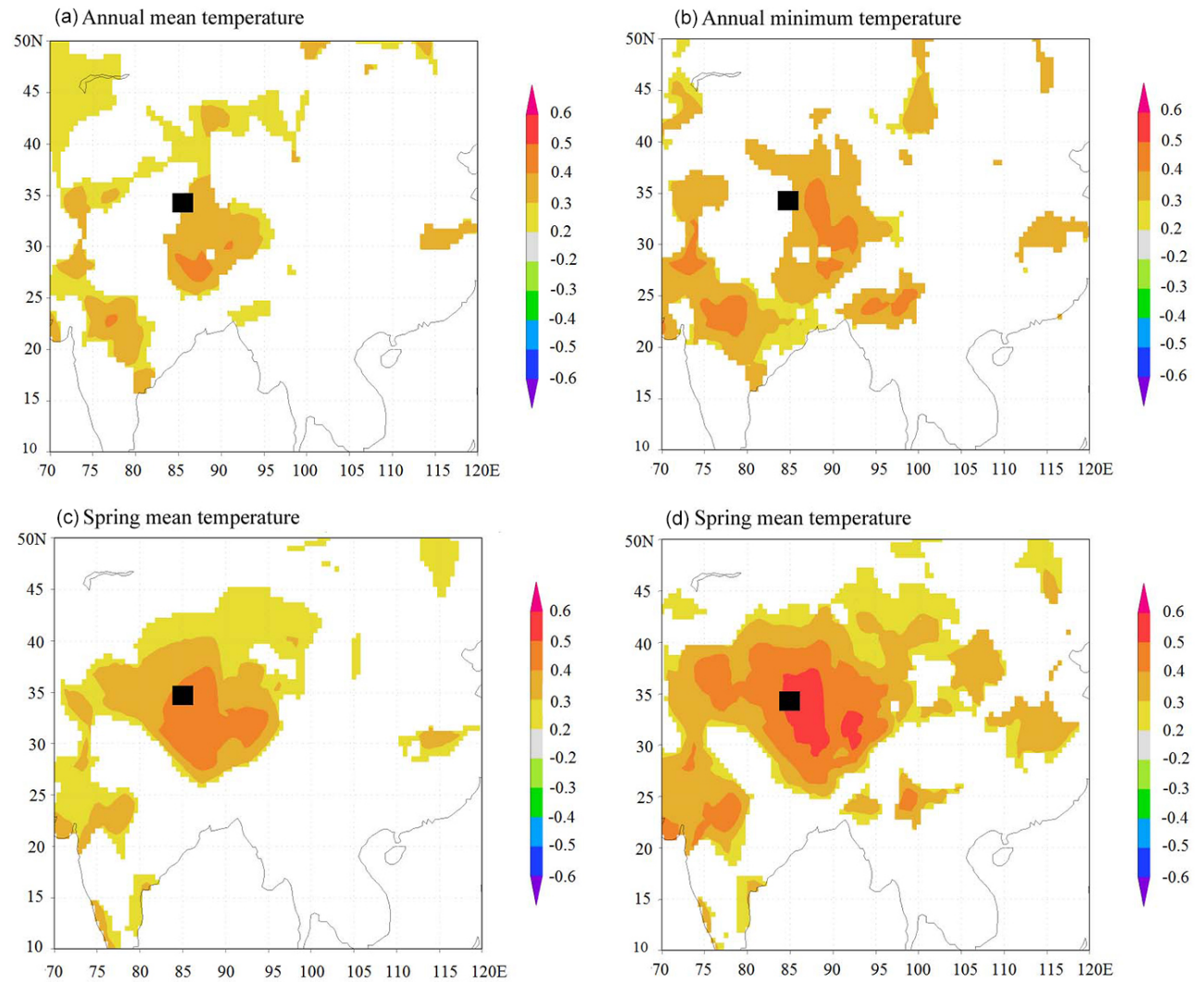

Figure 4. Spatial correlations of ZK ice core $\delta^{18} \mathrm{O}$ record with CRU gridded (Mitchell and Jones, 2005) annual mean temperature (a), annual minimum temperature (b), spring mean temperature (c), and spring minimum temperature (d) for the period 1951-2008. Only correlation coefficients significant at $p<0.01$ are shown. The black rectangle indicates the ZK ice core site.

Table 3. Correlation coefficients between the $\delta^{18} \mathrm{O}$ values in the ZK (1951-2008), Muztagata (1955-2002), Puruogangri (1951-1998), Geladaindong (1951-2004), and Malan (1951-1999) ice cores, and the regional $\delta^{18}$ O values (1951-2002) averaged from ZK, Muztagata, Puruogangri, and Geladaindong ice cores. The values in bold are the correlation coefficients of annual values, and the values in italic are the correlation coefficients of 5-year running average values.

\begin{tabular}{lrrrrrr}
\hline & ZK & Muztagata & Puruogangri & Geladaindong & Malan & Regional average \\
\hline ZK & & $\mathbf{0 . 2 6}$ & $\mathbf{0 . 1 4}$ & $-\mathbf{0 . 0 2}$ & $-\mathbf{0 . 2 7}$ & $\mathbf{0 . 5 7}$ \\
Muztagata & $0.68^{* * *}$ & & $\mathbf{0 . 0 9}$ & $\mathbf{0 . 0 4}$ & $-\mathbf{0 . 2 0}$ & $\mathbf{0 . 8 0}^{* * *}$ \\
Puruogangri & $0.46^{* * *}$ & 0.28 & & $-\mathbf{0 . 0 8}$ & $\mathbf{0 . 1 7}$ & $\mathbf{0 . 5 3}^{* * *}$ \\
Geladaindong & -0.07 & 0.24 & -0.12 & & $\mathbf{0 . 0 5}$ & $\mathbf{0 . 3 0}^{*}$ \\
Malan & $-0.40^{* *}$ & -0.33 & 0.14 & 0.18 & & \\
Regional average & $0.79^{* * *}$ & $0.95^{* * *}$ & $0.54^{* * *}$ & $0.31^{*}$ & & \\
\hline
\end{tabular}

${ }^{*} p<0.05 ;{ }^{* *} p<0.01 ;{ }^{* * *} p<0.001$.

cal climate conditions (Table 3), such as the influence of local convective vapor due to its more northern location (Kang et al., 2007). However, the ice cores of ZK, Muztagata, Puruogangri, and Geladaindong shared similar patterns of $\delta^{18} \mathrm{O}$ variations, especially their increasing trends since the 1970s (Fig. 4). Moreover, the regional composite with Geladaindong records correlates very strongly with that without Geladaindong ( $r=0.95,1951-2002, p<0.0001)$, and two series showed very similar temporal patterns (Fig. S2). Therefore, we decided to include the Geladaindong ice core $\delta^{18} \mathrm{O}$, so that the final regional reconstruction could have larger spatial coverage to better represent the regional climate of the northern TP. The regional temperature series was reconstructed for 1951-2002, the common period covered by the four ice core $\delta^{18} \mathrm{O}$ records. Meanwhile, a temperature reconstruction based solely on ZK ice core $\delta^{18} \mathrm{O}$ record 
was constructed for 1951-2008 to investigate the temperature variations since the late $1990 \mathrm{~s}$.

Before establishing the temperature reconstructions, it was necessary to derive the $\delta^{18} \mathrm{O}$-temperature relationship to understand the magnitude of the temperature variation over the northern TP. Yu et al. (2009) calculated the isotope sensitivity between monthly mean $\delta^{18} \mathrm{O}$ values in precipitation and the monthly mean temperatures at Gêrzê and Shiquanhe (Fig. 1) as 0.33 and $0.37 \% 0^{\circ} \mathrm{C}^{-1}$, respectively. State-of-the-art atmospheric models with integrated water isotopes modeling suggested an average isotope sensitivity of $0.53 \% 0^{\circ} \mathrm{C}^{-1}$ for the present-day precipitation falling at the grid where the ZK core was recovered (Risi et al., 2010). Tian et al. (2006) used the range of 0.6 to $0.7 \% 0^{\circ} \mathrm{C}^{-1}$ to convert the $\delta^{18} \mathrm{O}$ values to temperature for the Muztagata ice core. The isotope sensitivity usually increases with elevation, as indicated by a Rayleigh-type equilibrium fractionation model (Rowley et al., 2001). Kang et al. (2007) obtained $1.40 \%{ }^{\circ} \mathrm{C}^{-1} \delta^{18} \mathrm{O}$-temperature relationship from the linear regression between the 5-year running average of Geladaindong $\delta^{18} \mathrm{O}$ records and regional instrumental temperature records. In our study, the strongest correlation was found between the 5-year running average of the regional $\delta^{18} \mathrm{O}$ record and ITNTP $(r=0.89, p<0.001)$ (Fig. S3). The ZK $\delta^{18} \mathrm{O}$ correlates most strongly with the 5-year running average of the mean temperature from two nearby stations (Gêrzê and Xainza, $r=0.60, p<0.001$ ) (Table 1). Based on these significant relationships, the isotope sensitivities were determined as $1.46 \%{ }^{\circ} \mathrm{C}^{-1}$ for the regional $\delta^{18} \mathrm{O}$ series and $1.18 \%{ }^{\circ} \mathrm{C}^{-1}$ for $\mathrm{ZK} \delta^{18} \mathrm{O}$ series, and they were used to reconstruct regional temperature series for the northern TP (RTNTP) and the ZK temperature series, respectively. Additional analysis showed that, as isotope sensitivity value increases, the response of decadal warming rate decreases, especially for the isotope sensitivity values greater than 1.0 (Fig. S4).

The reconstructed regional temperature for the northern TP (RTNTP) is presented in Fig. 5a together with the temperature reconstruction for the ZK ice core (Fig. 5b), ITNTP (Fig. 5c), and the global temperature series (Fig. 5d) for comparison. We first compared the RTNTP with the ITNTP and found strong correlation between the two temperature series $(r=0.65, p<0.001)$. Spatially, significant correlations also existed between the CRU gridded surface temperatures and the ITNTP ( $r=0.50$ to $0.60, n=42, p<0.01$ ), as well as between CRU and the RTNTP ( $r=0.40$ to $0.60, n=52$, $p<0.01$ ) over a large region (Fig. 6). The study area had the strongest correlations $(r>0.50, p<0.01)$. This suggested that the regional reconstruction adequately captured temperature variation on the northern $\mathrm{TP}$.

\subsection{Recent rapid warming trend over the northern TP}

The regional reconstruction was compared with the global annual temperature series (Fig. 5d) and the ITNTP (Fig. 5c) in order to investigate the recent warming trend since the 1970s. LOESS regression was used to smooth the data and estimate the general trend. The reconstruction captured the cooling period during the 1960 s, as well as the prominent warming since the 1970s to the end of the record, with the highest rate of increase being in the late 1990s (Fig. 5). For the period from 1970 to 2002, the RTNTP showed a more rapid warming trend at the rate of $0.51 \pm 0.07^{\circ} \mathrm{C}$ $(10 \mathrm{yr})^{-1}$ than that of the global temperature $\left(0.27 \pm 0.03^{\circ} \mathrm{C}\right.$ $\left.(10 \mathrm{yr})^{-1}\right)$. The RTNTP rate was also higher than the ITNTP rate of increase at $0.43 \pm 0.08^{\circ} \mathrm{C}(10 \mathrm{yr})^{-1}$ for the same time period. From 1990 to 2002, the warming accelerated on the northern TP with rates of temperature increase at $0.95 \pm 0.21{ }^{\circ} \mathrm{C}(10 \mathrm{yr})^{-1}$ for the RTNTP and $0.90 \pm 0.29^{\circ} \mathrm{C}$ $(10 \mathrm{yr})^{-1}$ for the ITNTP, much higher than the warming rate of the global temperature $\left(0.37 \pm 0.13^{\circ} \mathrm{C}(10 \mathrm{yr})^{-1}\right)$. These results seemed to indicate enhanced warming at the highelevation regions on the northern TP.

Since the late 1990s, the global temperature has shown very little change and even a decreasing trend since 2005 (Fig. 5d). The relatively flat warming trend was also recorded in the ITNTP (Fig. 5b). However, the ZK series revealed a continued warming trend in recent years after a brief pause during the early 2000s (Fig. 5b). We calculated mean decadal annual temperature change based on the LOESS regression model for all three time series (Fig. 7). For both the global temperature and ITNTP series, the highest average warming rates occurred during the 1990s and then decreased significantly beginning in 1999 (Fig. 7c and d). The reduction of the warming rate in the ITNTP series was consistent with results by Duan and Xiao (2015), who found a weaker warming trend during the period 1998-2013 in the northern TP based on the instrumental temperature records. However, the rates of increase have remained high for the temperature records in the ZK series since 1999 (Fig. 7b), in contrast to the slowdown of climate warming observed for the global mean and ITNTP temperature records since 1999 (Fig. 7d). The persistent high warming rates derived from our regional reconstructions seem to suggest that the elevation-dependent warming is still evident over the high elevations of the northern TP despite the reduced warming rates observed at lower stations in ITNTP (Fig. S5).

The persistent rapid warming in the northern TP could have been caused by the regional radiative and energy budget changes (K. Yang et al., 2014; Yan and Liu, 2014; Duan and Xiao, 2015). Many studies show that the snow/ice-albedo feedback is an important mechanism for enhanced warming at high-elevation regions (Liu and Chen, 2000; Pepin and Lundquist, 2008; Rangwala and Miller, 2012). Ghatak et al. (2014) found that the surface albedo has been decreasing more at higher elevations than lower elevations over the TP in recent years. Qu et al. (2013) observed a decreasing trend for the snow/ice albedo at the Nyainquentanglha glacier region, central TP, for the period 2000 to 2010. It has been found that the glacier albedo for the nine glaciers in western China has decreased during the period 2000-2011, especially for 
(a) RTNTP

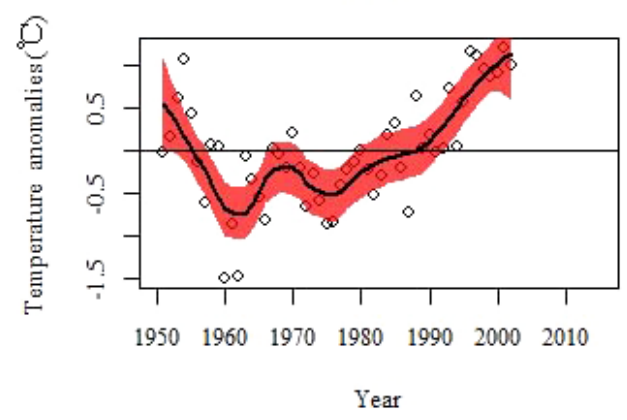

(c) ITNTP

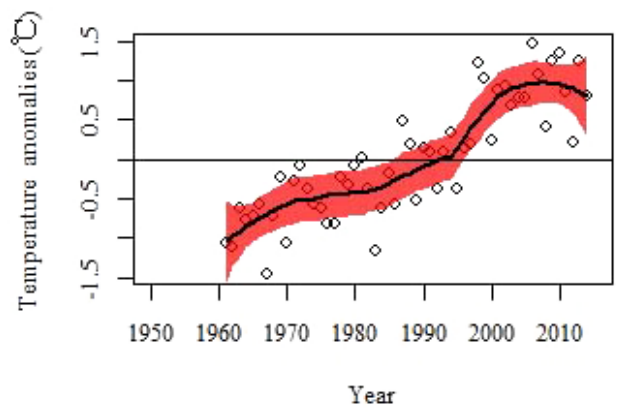

(b) ZKT

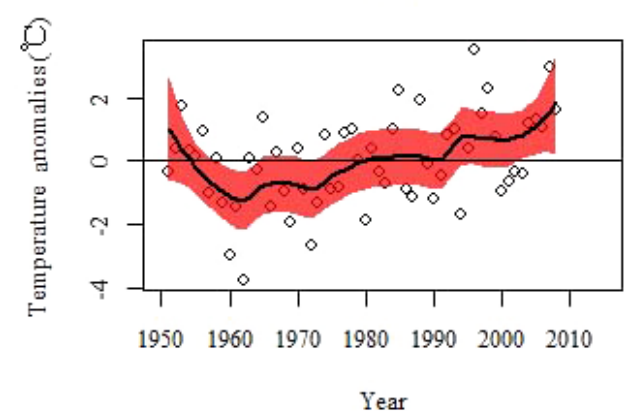

(d) Global

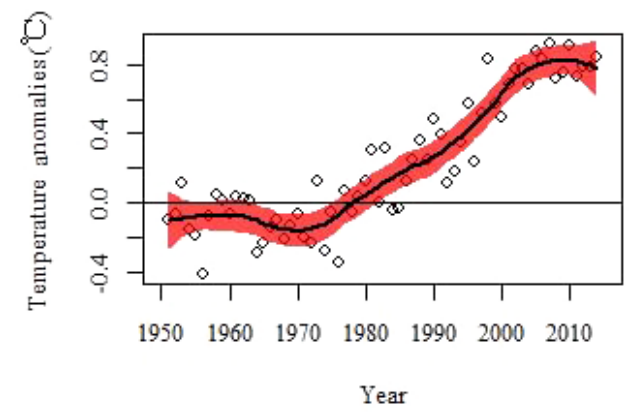

Figure 5. The reconstructed regional temperature series for the northern Tibetan Plateau (RTNTP) from ZK, Muztagata, Puruogangri, and Geladaindong ice core $\delta^{18} \mathrm{O}$ records (a), the reconstructed temperature series from the ZK ice core $\delta^{18} \mathrm{O}$ record (b), the instrumental temperature record for the northern TP (ITNTP) (c), and global average temperature (d). Black trend lines were estimated using the nonparametric LOESS regression technique with a span of 0.4 ; the dots indicate the raw values of corresponding temperature series; shading represents the $95 \%$ confidence intervals of the estimated trends.

(a) ITNTP

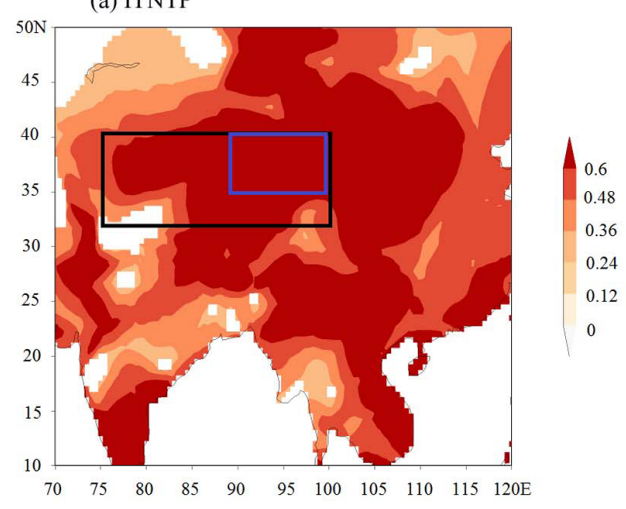

(b) Regional reconstruction

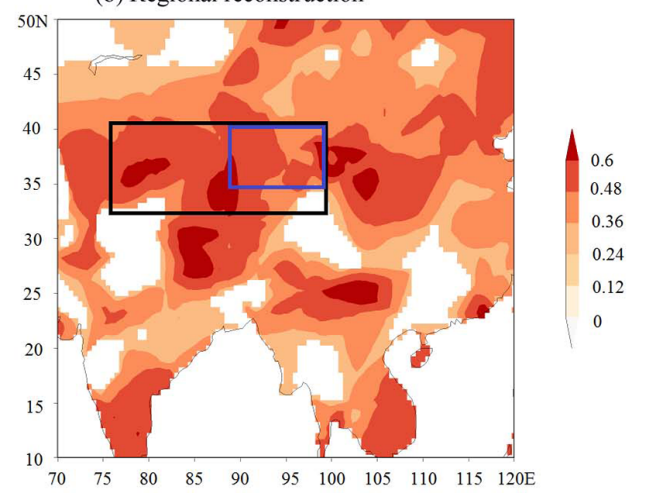

Figure 6. Spatial correlations ( $r$ values in color, $p<0.01$ ) between the gridded annual mean temperature data (the CRU 4 temperature time series, $0.5^{\circ} \times 0.5^{\circ}$ resolution; Mitchell and Jones, 2005) and the instrumental temperature record of the northern TP (ITNTP) (Guo and Wang, 2011) for the period 1961-2002 (a), and the regional temperature reconstruction series for the period 1961-2002 (b). The black rectangle indicates the study area, and the blue rectangle indicates the region covered by ITNTP.

the central TP (J. Wang et al., 2014). For example, the glacial albedo of Dongkemadi and Puruogangri glaciers decreased at a rate of $0.0043-0.0059$ and $0.001-0.004 \mathrm{yr}^{-1}$, respectively. Reduced surface albedo increases the surface absorption of solar radiation, and it may have contributed to the continued warming over the high-elevation regions of the northern TP. Further research is needed to identify and quantify the exact mechanisms accounting for the temperature variations over the plateau. 

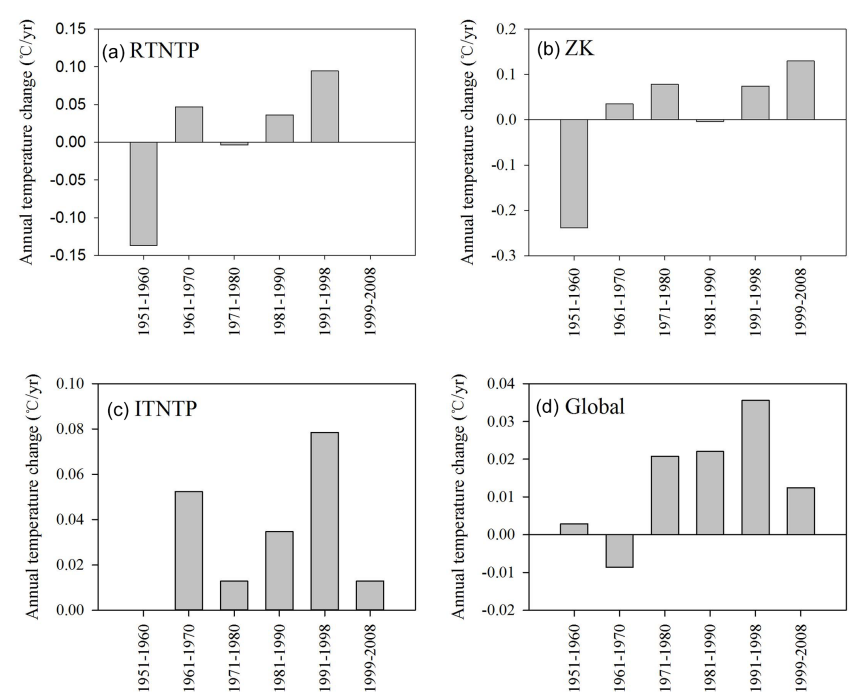

Figure 7. Decadal mean annual change rates for the regional temperature reconstruction series for the northern TP (RTNTP) (a), the temperature reconstruction from the $\mathrm{ZK}$ ice core $\delta^{18} \mathrm{O}$ record (ZK) (b), the instrumental temperature record of the northern TP (ITNTP) (c), and global average temperature (d). The decadal mean annual change rates were estimated using the non-parametric LOESS regression model with a span of 0.4 .

\section{Conclusions}

This study presented a $\delta^{18} \mathrm{O}$ time series of the $\mathrm{ZK}$ ice core from the northern TP, based on which a temperature record was reconstructed for the period 1951-2008. Moreover, by combining the $\mathrm{ZK} \delta^{18} \mathrm{O}$ with three other ice cores from the northern TP, a regional temperature history was established from 1951 to 2002. These temperature reconstructions captured the rapid warming trend since 1970 and showed continued warming since 1999 at much higher rates than those of the global average temperature and the instrumental temperature records for the northern TP.

Possible explanations for this continued warming might lie in the regional radiative and energy changes at higher elevations over the northern TP. However, the exact physical mechanisms responsible for the consistently significant warming at higher elevations remain unclear, partly due to the scarcity of available observations. Further studies are needed to understand the specific characteristics of this warming trend on the TP, as well as the response mechanisms of high-elevation regions to global changes.

\section{The Supplement related to this article is available online at doi:10.5194/cp-12-201-2016-supplement.}

Acknowledgements. Thanks are due to many scientists, technicians, graduate students, and porters for their hard work in the field. We would also like to thank $\mathrm{Hao} \mathrm{Xu}$, Yaju Li, Chaomin Wang, Hao Hou, Rong Hua, Jing He, and Yanying Tang for their help in the laboratories. This work was supported by the Natural Science Foundation of China (41330526, 41171052, and 41321062) and the Chinese Academy of Sciences (XDB03030101-4).

Edited by: V. Masson-Delmotte

\section{References}

Araguás-Araguás, L., Froehlich, K., and Rozanski, K.: Stable isotopic composition of precipitation over southeast Asia, J. Geophys. Res., 103, 28721-28742, doi:10.1029/98JD02582, 1998.

Dansgaard, W.: Stable isotopes in precipitation, Tellus, 16, 436468, doi:10.1111/j.2153-3490.1964.tb00181.x, 1964.

Duan, A. M. and Xiao, Z. X.: Does the climate warming hiatus exist over the Tibetan Plateau?, Scientific Reports, 5, 13711, doi:10.1038/srep13711, 2015.

Easterling, D. R. and Wehner M. F.: Is the climate warming or cooling?, Geophys. Res. Lett., 36, L08706, doi:10.1029/2009GL037810, 2009.

Ghatak, D., Sinsky, E., and Miller. J.: Role of snow-albedo feedback in higher elevation warming over the Himalayas, Tibetan Plateau and Central Asia, Environ. Res. Lett., 9, 114008, doi:10.1088/1748-9326/9/11/114008, 2014.

Guo, D. L. and Wang, H. J.: The significant climate warming in the northern Tibetan Plateau and its possible causes, Int. J. Climatol., 32, 1775-1781, doi:10.1002/joc.2388, 2011.

He, Y., Risi, C., Gao, J., Masson-Delmotte, V., Yao, T. D., Lai, C. T., Ding, Y. J., Worden, J., Frankenberg, C., Chepfer, H., and Cesana, G.: Impact of atmospheric convection on south Tibet summer precipitation isotopologue composition using a combination of in situmeasurements, satellite data, and atmospheric general circulation modeling, J. Geophys. Res., 120, 3852-3871, doi:10.1002/2014JD022180, 2015.

He, Y. X., Zhao, C., Wang, Z., Wang, H. Y., Song, M., Liu, W. G., and Liu, Z. H.: Late Holocene coupled moisture and temperature changes on the northern Tibetan Plateau, Quaternary Sci. Rev., 80, 47-57, doi:10.1016/j.quascirev.2013.08.017, 2013.

Herzschuh, U., Mischke, H. J. S., Zhang, C. J., and Böhner, J.: A modern pollen-climate calibration set based on lake sediments from the Tibetan Plateau and its application to a Late Quaternary pollen record from the Qilian Mountains, J. Biogeogr., 37, 752766, doi:10.1111/j.1365-2699.2009.02245.x, 2010.

Hou, S. G., Ren, J. W., and Qin, D. H.: Modification of three icecore $\delta^{18} \mathrm{O}$ records from an area of high melt, Ann. Glaciol., 43, 172-176, doi:10.3189/172756406781812140, 2006.

Joswiak, D. R., Yao, T., Wu, G., Xu, B., and Zheng, W.: A 70-yr record of oxygen-18 variability in an ice core from the Tanggula Mountains, central Tibetan Plateau, Clim. Past, 6, 219-227, doi:10.5194/cp-6-219-2010, 2010.

Joswiak, D. R., Yao, T., Wu, G., Tian, L., and Xu, B.: Icecore evidence of westerly and monsoon moisture contributions in the central Tibetan Plateau, J. Glaciol., 59, 56-66, doi:10.3189/2013JoG12J035, 2013.

Kang, S. C., Zhang, Y. J., Qin, D. H., Ren, J. W., Zhang, Q. G., Bjorn, G., and Mayewski, P. A.: Recent temperature increase 
recorded in an ice core in the source region of Yangtze River, Chinese Sci. Bull., 52, 825-831, doi:10.1007/s11434-007-0140$1,2007$.

Lang, T. J. and Barros, A. P.: Winter storms in the central Himalayas, J. Meteorol. Soc. Jpn., 82, 829-844, doi:10.2151/jmsj.2004.829, 2004.

Liu, X. D. and Chen, B. D.: Climatic warming in the Tibetan Plateau during recent decades, Int. J. Climatol., 20, 17291742, doi:10.1002/1097-0088(20001130)20:14<1729::AID25JOC556>3.0.CO;2-Y, 2000.

Mitchell, T. D. and Jones, P. D.: An improved method of constructing a database of monthly climate observations and associated high-resolution grids, Int. J. Climatol., 25, 693-712, doi:10.1002/joc.1181, 2005.

Pang, H., Hou, S., Kaspari, S., and Mayewski, P. A.: Influence of regional precipitation patterns on stable isotopes in ice cores from the central Himalayas, The Cryosphere, 8, 289-301, doi:10.5194/tc-8-289-2014, 2014.

Pepin, N. and Lundquist, J.: Temperature trends at high elevations: patterns across the globe, Geophys. Res. Lett., 35, L14701, doi:10.1029/2008GL034026, 2008.

Pu, Y., Zhang, H. C., Wang, Y. L., Lei, G. L., Nace, T., and Zhang, S. P.: Climatic and environmental implications from nalkanes in glacially eroded lake sediments in Tibetan Plateau: An example from Ximen Co, Chinese Sci. Bull., 56, 1503-1510, doi:10.1007/s11434-011-4454-7, 2011.

Qin, D. H., Hou, S. G., Zhang, D. Q., Ren J. W., and Kang, S. C.: Preliminary results from the chemical records of an $80.4 \mathrm{~m}$ ice core recovered from East Rongbuk Glacier, Qomolangma (Mount Everest), Ann. Glaciol., 35, 278-284, doi:10.3189/172756402781816799, 2002.

$\mathrm{Qu}, \mathrm{B} .:$ Albedo changing and its impact factors in the glacier area of Mt. Nyainquentanglha region, Beijing, University of Chinese Academy of Sciences, 35-36, 2013.

Rangwala, I. and Miller, J.: Climate change in mountains: a review of elevation dependent warming and its possible causes, Climatic Change, 114, 527-547, doi:10.1007/s10584-012-0419-3, 2012.

Risi, C., Bony, S., Vimeux, F., and Jouzel, J.: Water-stable isotopes in the LMDZ4 general circulation model: Model evaluation for present - day and past climates and applications to climatic interpretations of tropical isotopic records, J. Geophys. Res., 115, D12118, doi:10.1029/2009JD013255, 2010.

Rowley, D. B., Pierrehumbert, R. T., and Currie, B. S.: A new approach to stable isotope-based paleoaltimetry: implications for paleoaltimetry and paleohypsometry of the High Himalaya since the Late Miocene, Earth Planet. Sc. Lett., 188, 253-268, doi:10.1016/S0012-821X(01)00324-7, 2001.

Shi, Y. F.: Concise Glacier Inventory of China, Shanghai Science Press, Shanghai, 2008.

Tang, Y., Pang, H., Zhang, W., Li, Y., Wu, S., and Hou, S.: Effects of changes in moisture source and the upstream rainout on stable isotopes in precipitation - a case study in Nanjing, eastern China, Hydrol. Earth Syst. Sci., 19, 4293-4306, doi:10.5194/hess-194293-2015, 2015.

Thompson, L. G., Yao, T., Mosley-Thompson, E., Davis, M .E., Henderson, K. A., and Lin, P. N.: A high-resolution millennial record of the South Asian monsoon from Himalayan ice cores, Science, 289, 1916-1919, doi:10.1126/science.289.5486.1916, 2000 .
Tian, L. D., Yao, T. D., Li, Z., MacClune, K., Wu, G. J., Xu, B. Q., Li, Y. F., Lu, A. X., and Shen, Y. P.: Recent rapid warming trend revealed from the isotopic record in Muztagata ice core, eastern Pamirs, J. Geophys. Res., 111, D13103, doi:10.1029/2005JD006249, 2006.

Wang, J., Ye, B. S., Cui, Y. H., He, X. B., and Yang, G. J.: Spatial and temporal variations of albedo on nine glaciers in western China from 2000 to 2011, Hydrol. Process, 28, 3454-3465, doi:10.1002/hyp.9883, 2014.

Wang, N., Yao, T. D., Pu, J. C., Zhang, Y. L., Sun, W. Z., and Wang, Y. Q.: Variations in air temperature during the last 100 years revealed by $\delta^{18} \mathrm{O}$ in the Malan ice core from the Tibetan plateau, Chinese Sci. Bull., 48, 2134-1238, doi:10.1360/02wd0539, 2003.

Wang, Y. Q., Pu, J. C., Zhang, Y. L., and Sun, W. Z.: Characteristic of present warming change recorded in Malan ice core, central Tibetan Plateau, J. Glaciol. Geocryol., 25, 130-134, 2003 (in Chinese with English abstracts).

Yang, B., Qin, C., Wang, J. L., He, M. H., Melvin, T. M., Osbornb, T. J., and Briffa, K. R.: A 3,500-year tree-ring record of annual precipitation on the northeastern Tibetan Plateau, P. Natl. Acad. Sci. USA, 111, 2903-2908, doi:10.1073/pnas.1319238111, 2014.

Yang, K., Wu, H., Qin, J., Lin, C. G., Tang, W. J., and Chen, Y. Y.: Recent climate changes over the Tibetan Plateau and their impacts on energy and water cycle: A review, Global Planet. Change, 112, 79-91, doi:10.1016/j.gloplacha.2013.12.001, 2014.

Yan, L. B. and Liu, X. D.: Has Climatic Warming over the Tibetan Plateau Paused or Continued in Recent Years?, J. Earth Ocean Atmos. Sci., 1, 13-28, 2014.

Yang, X. X., Yao, T. D., Joswiak, D., and Yao, P.: Integration of Tibetan Plateau ice-core temperature records and the influence of atmospheric circulation on isotopic signals in the past century, Quaternary Res., 81, 520-530, doi:10.1016/j.yqres.2014.01.006, 2014.

Yao, T. D., Guo, X. J., Lonnie, T., Duan, K. Q., Wang, N. L., Pu, J. C., Xu, B. Q., Yang, X. X., and Sun, W. Z.: $\delta^{18} \mathrm{O}$ record and temperature change over the past 100 years in ice cores on the Tibetan Plateau, Sci. China Ser. A, 49, 1-9, doi:10.1007/s11430004-5096-2, 2006.

Yao, T. D., Thompson, L., Yang, W., Yu, W. S., Gao, Y., Guo, X. J., Yang, X. X., Duan, K. Q., Zhao, H. B., Baiqing Xu, B. Q., Pu, J. C., Anxin Lu, A. X., Xiang, Y., Kattel D. B., and Joswiak, D.: Different glacier status with atmospheric circulations in Tibetan Plateau and surroundings, Nature Climate Change, 2, 663-667, doi:10.1038/nclimate1580, 2012.

Yao, T. D., Masson-Delmotte, V., Gao, J., Yu, W. S., Yang, X. X., Risi, C., Sturm, C., Werner, M., Zhao, H. B., He, Y., Ren, W., Tian, L. D., Shi, C. M., and Hou, S. G.: A review of climatic controls on $\delta^{18} \mathrm{O}$ in precipitation over the Tibetan Plateau: Observations and simulations, Rev. Geophys., 51, 525548, doi:10.1002/rog.20023, 2013.

Yu, W. S., Ma, Y. M., Sun, W. Z., and Wang, Y.: Climatic significance of $\delta^{18} \mathrm{O}$ records from precipitation on the western Tibetan Plateau, Chinese Sci. Bull., 54, 2732-2741, doi:10.1007/s11434009-0495-6, 2009.

Zhang, W. B., Hou, S. G., An, W. L., Zhou, L. Y., and Pang, H. X.: Variations of atmospheric dust loading since 1951 AD recorded 
in an ice core from the North Tibet Plateau, Ann. Glaciol., 57, doi:10.3189/2016AoG71A559, 2016.
Zheng, W., Yao, T. D., Joswiak, D. R., Xu, B. Q., Wang, N. L., and Zhao, H. B.: Major ions compostion records from a shallow ice core on Mt. Tanggula in the central Qinghai-Tibetan Plateau, Atmos. Res., 97, 70-79, doi:10.1016/j.atmosres.2010.03.008, 2010 . 